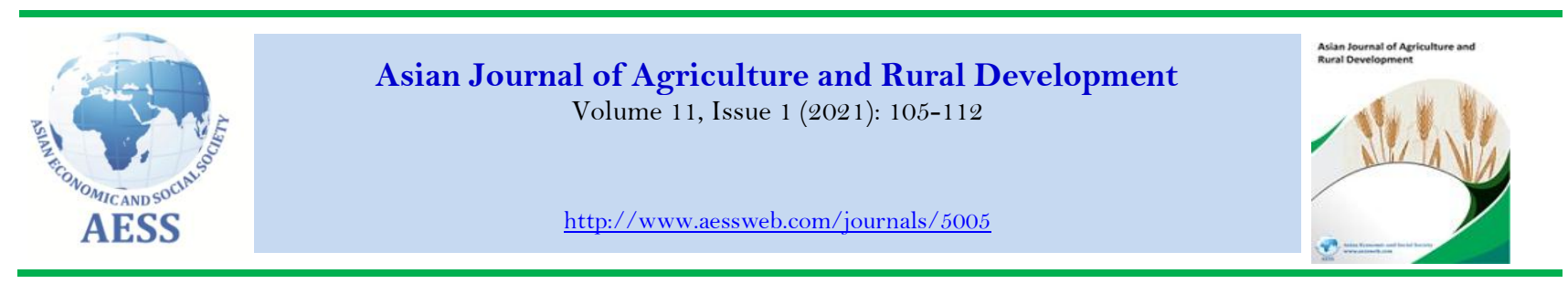

\title{
NEMATODE ATTACKS AND THEIR INFLUENCE ON FARMING ECONOMICS
}

\author{
Rosmiza M. Z. ${ }^{1}$ \\ Muhammad Zaim Samion ${ }^{2}$ \\ Milah Zainal ${ }^{s}$ \\ Mohd Nor Mohd Rosmi ${ }^{4}$
}

\author{
${ }^{1,2}$ Geography Program, Center for Research in Development, Social and Environment, \\ Faculty of Social Sciences and Humanities, Universiti Kebangsaan Malaysia, Malaysia. \\ ${ }^{3}$ Professional Development and Continuing Education, Faculty of Educational Studies, \\ Universiti Putra Malaysia, Malaysia. \\ ${ }^{4}$ Biotechnology and Nanotechnology Research Centre, Malaysian Agricultural Research \\ and Development Institute (MARDI), Selangor, Malaysia. \\ - $\underline{\text { miza@ukm.edu.my }}$ (Corresponding author)
}

\section{Article History}

Received: 4 January 2021

Revised: 27 January 2021

Accepted: 10 February 2021

Published: 23 February 2021

\section{Keywords}

Farming economics

Food security

Nematodes

Nematode attacks

Rice diseases

Rice yields.

\begin{abstract}
Nematode attack is among the factors significantly reducing the world's rice production, to the extent of affecting farming economics and global food security. One of the factors involved in the decline in production is the prevalence of rice diseases and pests, among which are nematodes. Therefore, this study was conducted to identify the level of farmers' knowledge on the symptoms of nematode infection in Pasir Panjang, which is situated in the rice cultivation area, namely Integrated Agricultural Development Area (IADA), of Northwest Selangor. The study also analyzed the effects of nematode attacks on farming economics. Descriptive analysis was performed on 86 randomly selected samples of farmers whose crops had often been attacked by nematodes. The results of the study found that the farming community had knowledge of the symptoms of nematode infestation in rice crop fields. Analysis of the study results showed that farmers were significantly affected by nematode attacks on their rice crops. The effects of attack could be seen from the reduced income and economic levels of the farmers and consequent increase in management costs, in addition to the increasing costs of purchasing pesticides and fertilizers. Production output and yield quality also declined. This situation has negatively impacted the quality of life of these farmers. The implications of this study inform the strategies for integrated and continuous disease and pest control to ensure that the country's food security is more stable.
\end{abstract}

Contribution/Originality: The paper's primary contribution is the finding that nematode attacks are seen to have a negative impact on farming economics and farmers' quality of life. They are also a major threat to the country's rice supply security. Therefore, handling strategies using environmental friendly methods involving control and prevention need to be strengthened so that nematode attacks can be overcome effectively.

DOI: 10.18488/journal.ajard.2021.111.105.112

$\operatorname{ISSN}(\mathrm{P}):$ 2304-1455/ ISSN(E): 2224-4433

How to cite: Rosmiza M. Z. --- Muhammad Zaim Samion --- Milah Zainal --- Mohd Nor Mohd Rosmi (2021). Nematode Attacks and their Influence on Farming Economics. Asian Journal of Agriculture and Rural Development, 11(1), 105-112. 10.18488/journal.ajard.2021.111.105.112

(C) 2021 Asian Economic and Social Society. All rights reserved. 


\section{INTRODUCTION}

Global rice yield productivity shows a declining trend from 2017 to 2019. This is due to several factors, including climate change, pest attacks and rice diseases, and limited agricultural area (Ilakiya \& Kalaivani, 2020; Nguyen \& Ferrero, 2006). According to Nurul and Kalaivani (2014) and Pam (2019), a survey on crop health found that diseases and pests were among the main causes of huge losses of crop yields, as well as weed populations (Mardiana-Jansar, Bajrai, Ishak, \& Ismail, 2019). At a global scale, pathogens and pests are causing losses of 10-28\% in wheat, in rice $(25-41 \%)$, maize $(20-41 \%)$, potatoes $(8-21 \%)$, and soybeans $(11-32 \%)$ (Gonzalez-Chang, Tiwari, Sharma, \& Wratten, 2019). In fact, according to Nguyen and Ferrero (2006), the problem of rice pests, including nematode attacks, has caused annual crop losses of up to $25 \%$. It is clear that diseases and pests are among the problems for farmers that are threatening their crops to the extent of causing a decline in agricultural yields.

Nematodes are invertebrates, a type of worm or microscopic parasite in the shape of a long circle, mostly metazoans (Bird, Opperman, \& Davies, 2003; Davies, 2009; Decraemer \& Hunt, 2006; Maisarah et al., 2018; Pracaya, 2008). More than 90 species of nematode have been recorded, and most are inactive endoparasites (Crow \& Dunn, 2009; Decraemer \& Hunt, 2006; Perry, Moens, \& Starr, 2009). The original habitat of this organism is soil or plants, with some living in water. Therefore, most of the symptoms of nematode attack are seen in the parts of crops below soil level - the roots and tubers. Nematodes live in plants by consuming the contents of root cells, stems, and leaves (Department of Agriculture Sarawak, 2020).

Generally, nematode attacks cause physical damage to the roots, stems, or leaves of plants. Their ability to attack crops, especially on the roots and leaves, can affect plant growth, yield, and production quality (Maisarah et al., 2018; Mirsam, 2018). The rate of damage to long-term crops is relatively low. The effect of nematode attack is more pronounced if the plant is under stress, such as during a long dry season (Department of Agriculture Sarawak, 2020). Serious nematode attacks pose a threat to a country's farming economy and food security (Auwal, Pham, Shi, \& Zheng, 2013; Fleming, McGowan, Maule, \& Fleming, 2016; Nicol et al., 2011).

Significant impact on the farming economy in terms of production and quality of yields due to nematode attacks puts pressure on farmers and their quality of life. Accordingly, a study was conducted to assess the level of farmers' knowledge of the symptoms of nematode attack and its influence on their finances. The implications of this study are expected to enable formulation of control strategies to overcome the problem of continuous nematode attacks so that farmers' quality of life is more secure, through increased productivity and the quality of their rice crops. This will also guarantee the security of the country's rice supply.

\section{LITERATURE REVIEW}

\subsection{Symptoms and their Influence on Rice Tields and the Farming Economy}

Generally, crops attacked by nematodes show symptoms such as slow growth rate, stunted growth, leaf chlorosis and leaves falling off easily. However, these symptoms vary depending on the type of nematode that attacks the plant. These are (1) root knot nematode (Meloidogyne sp.), (2) leaf nematode (Aphelenchoides sp.), (3) lesion nematode (Pratylenchus sp.) and (4) rice root nematode (Hirschmanniella sp.) (Maisarah \& Azmi, 2015; Mulyadi. \& Triman, 1995; Nurjayadi, Munif, \& Suastika, 2015; Smiley, 2015).

Even though various methods have recently been introduced in developed countries to overcome pests, nematode attacks still affect crop yields by $5-10 \%$ (Nicol, 2002). Based on studies by Sasser and Freckman (1987), nematodes cause a yield loss of about $17-20 \%$, equivalent to US $\$ 100$ billion annually (Bird et al., 2003). In addition, plantparasitic nematodes have resulted in a reduction in the quantity and quality of crop yields in the agricultural sector (Bird \& Bird, 2001; Handoo, 1998).

The symptoms of disease and damage to crops that are visible above the soil surface reflect the damaged root system as a result of nematode disturbance. Because of damage to the root system, the plant shows symptoms of nutrient deficiency, the leaves turn yellow and wither, the growth of the plant is stunted, and eventually the plant will die (Maisarah \& Azmi, 2015). Besides direct physical damage, nematodes also encourage other pathogenic infections such as bacteria and fungi. For example, root knot nematodes mutually interact with Fusarium solani, resulting in severe damage to plants (Department of Agriculture Sarawak, 2020).

According to Atkins et al. (2003), Koenning et al. (1999), Sasser (1977), and Perry et al. (2009), root knot nematodes are among the most common parasitic genera of plants and the main crop pests in the world (Fofie \& Raymundo, 1979; Ruben et al., 1998); however, attacks are commonly more extreme in the tropics and subtropics (Moens, Perry, \& Starr, 2009; Perry et al., 2009). Rice agriculture, especially in Asia, has major concerns concerning root knot nematode, as new approaches in agriculture due to environmental (climate change) and socioeconomic factors have resulted in a drastic rise in the prevalence of Meloidogyne graminicola $(\mathrm{Mg})$ (De Waele \& Elsen, 2007). Galls in a shape of a hook (root swellings) develop mainly at the infected plant root tips. As water and nutrients cannot be transported due to changes in the root vascular system, symptoms will develop on the upper part of the plant including loss of vigor, stunting, and chlorosis, contributing to poor crop growth and reproduction (Fahiem \& Larry, 2005; Karssen \& Moens, 2006; Mantelin, Bellafiore, \& Kyndt, 2017; Michel, Richard, \& John, 2005), which may account for up to $87 \%$ of production losses (Netscher \& Erlan, 1993). According to Mulyadi (1997), the influence of root knot nematode on rice growth and yield - that is with $\mathrm{Mg}$ treatment at 16.0 heads $/ \mathrm{ml}$ of soil - can cause $70.0 \%$ death of seedlings at the age of 20 days and $38.5 \%$ decrease in yield production.

A study by Sari (2017) in Indonesia on five varieties of rice, namely IPB 3S, HIPA 14, Sintanur, Pertiwi 1, and Ciherang, found that the influence of leaf nematode attack (Aphelenchoides sp.) caused a decrease in high yields for all varieties of crop studied. On average, there was a decrease in yield of $30.0 \%$ while total decline in the growth of seedlings was $50.0 \%$ and in total number of rice seeds was 15.0\%. According to Teuku (2018), attacks by leaf 
nematodes on the IPB $3 \mathrm{~S}$ rice variety in Purwakarta, West Java on average showed a decrease in plant height to 75 $\mathrm{cm}$ compared to the normal height of $88.5 \mathrm{~cm}$. The number of seedlings decreased to six, whereas the normal number was nine, and the average incidence rate was up to $60.0 \%$.

Apart from the foregoing, there are three types of leaf nematode species, namely Aphelenchoides besseyi, Aphelenchoides fragariae, and Aphelenchoides itzemabosi, that have greatly impacted the economy, causing losses in various agricultural and horticultural crops (Duncan \& Moens, 2013). A. besseyi, for example, can cause white tips on leaves, the affected parts then turnung dry and curly (Fahiem \& Larry, 2005; Kepenekci, 2013). It is reported that leaf nematode attacks have infected more than 200 species of plant including rice, strawberries, and ornamentals (Cheng et al., 2013; Duncan \& Moens, 2013). According to Tülek et al. (2014), Cheng et al. (2013), and De Jesus et al. (2016), $A$. besseyi attacks have affected rice crops resulting in loss of yield of 5.4-57.9\% in Turkey and $71 \%$ in China. These attacks have caused losses to the farming community due to the increased costs of crop management. In Malaysia, nematode attacks are also causing reduced yields in rice (Abdul Karim, 1991; Maisarah et al., 2018; Nicol et al., 2011), resulting in farmers suffering losses due to markedly reduced income.

Studies by Fahiem and Larry (2005), Nurjayadi et al. (2015), Michael, Claude, David, Thierry, and Elisavet (2018), and Goswami, Archana, Neetu, and Satyendra (2015) found that the symptoms of rice root nematode attack include decreased seedling production and delayed flowering of up to 14 days and above. In fact, Michel et al. (2005) recorded the symptom of roots turning brownish yellow. Eventually, the stem of the rice plant will rot after being attacked.

The lesion nematode genus is Pratylenchus. Symptoms of attack by this nematode can be found on the panicle, spike, and spikelets (Fahiem \& Larry, 2005). This species will infect the host plant causing stem lesions (Brooks, 2013; Crow, 2013; Mitiku, 2018; Perry \& Moens, 2013). Lesions, which are initially brownish gray in color, will turn yellow on the leaves of a 22-day-old plant. This will cause the plant to become stunted, chlorotic, and wither, and eventually it will die (Michel et al., 2005). Attacks can result in significant loss of crop yield and are capable of causing secondary infections by bacteria and fungi as a result of the lesions (Perry \& Moens, 2013).

It is clear that nematode attacks on rice crops will increase crop management costs, especially regarding the purchase of pesticides and fertilizers. Continuous attacks will affect farmers' income and quality of life (Rosmiza, Amriah, Rosniza, Jabil, \& Mazdi, 2015; Xing et al., 2017). According to Briggs (2000) and Heong, Wong, and Reyes (2013), the use of appropriate pesticides and fertilizers is very important in overcoming the problems of rice diseases. However, nematodes will become resistant to pesticides when these are used over a long period. In fact, commonly used pesticides will not have any effect on diseases recently encountered. This puts pressure on farmers to bear additional costs for crop management, such as the purchase of pesticides and fertilizers. Farías (2020), Rosmiza, Rosniza, Jabil, and Mazdi (2019), and Fuad et al. (2012) found that prolonged use of chemical pesticides could have a negative impact not only on farmers, but also on the surrounding community and environmental. Thus, it is undeniable that rice diseases result in a progressive deterioration in farmers' quality of life.

\section{METHOD AND STUDY AREA}

A quantitative study design (survey) was used to study the influence of nematode attacks on farming economics in Pasir Panjang, Selangor. Descriptive analysis involving frequency, percentage, and convergence tendency (mean, variance, and standard deviation) was conducted to examine the types of nematode that most frequently attack rice plants, and the effects of attacks on farming communities. To obtain data in the field, questionnaires and observations were implemented. The Likert scale was used to assess farmers' level of knowledge on nematode attacks on cultivated rice crops. The Likert scale runs from 1 (Strongly disagree), 2 (Disagree), 3 (Somewhat disagree), and 4 (Agree) to 5 (Strongly agree). Observational methods were carried out at rice cultivation sites to thoroughly examine the types of nematode attack, as well as the symptoms of those attacks. This method of observation can give a clear picture of the symptoms of nematode attack and its effect on crop yields.

The rationale for selecting Pasir Panjang as the study area is because the location is located in the Integrated Agricultural Development Area (IADA) in Northwest Selangor, one of eight major rice-growing areas in Malaysia. The 19,057-ha IADA area consists of nine blocks of crops among which is the study area, Pasir Panjang. The Pasir Panjang block has a cultivation area of 1589 ha and a farming population of 601 . Purposive sampling was conducted by selecting farmers who cultivate rice, in addition to those having experienced nematode attacks. Based on sample size calculation by Yamane (1967), a total of 86 samples were randomly selected for the questionnaire.

\section{RESULTS AND DISCUSSION}

The majority of farmers (85) in the study who cultivate rice were men (98.8\%). Thirty-five of the 85 farmers (40.7\%) were aged 31-40 years. Most respondents were Malay (83, 96.5\%) and the rest were Chinese (3.5\%). The majority of respondents had a level of education up to secondary school only (47.7\%), and only one (1.2\%) had attained the educational level of a higher learning institution. Nevertheless, all respondents had had a formal education. None of the respondents earned less than RM500 per month, while the majority earned in the range RM1000-1500 per month (38.4\%), 31.4\% earned RM1501-1999 and 16.3\% earned more than RM2000 per month (Table 1). 
Table-1. Farmers' profile.

\begin{tabular}{l|l|c|c}
\hline Profile & Category & Frequency & Percentage \\
\hline \multirow{4}{*}{ Gender } & Male & 85 & 98.8 \\
\cline { 2 - 4 } & Female & 1 & 1.2 \\
\hline \multirow{5}{*}{ Age } & $18-20$ years & 3 & 3.5 \\
\cline { 2 - 4 } & $21-30$ years & 13 & 15.1 \\
\cline { 2 - 4 } & $31-40$ years & 35 & 40.7 \\
\cline { 2 - 4 } & $41-50$ years & 30 & 34.9 \\
\cline { 2 - 4 } & 51 and above & 5 & 5.8 \\
\hline \multirow{5}{*}{ Educe } & Malays & 83 & 96.5 \\
\cline { 2 - 4 } & Chinese & 3 & 3.5 \\
\hline & Primary school & 5 & 5.8 \\
\cline { 2 - 4 } & Secondary school & 41 & 47.7 \\
\cline { 2 - 4 } & High school & 19 & 22.1 \\
\cline { 2 - 4 } & Technical and vocational & 20 & 23.3 \\
\cline { 2 - 4 } & College/higher education institution & 1 & 1.2 \\
\hline \multirow{5}{*}{ Income } & RM500 & - & - \\
\cline { 2 - 4 } & RM501-RM999 & 12 & 14 \\
\cline { 2 - 4 } & RM1000-RM1500 & 33 & 38.4 \\
\cline { 2 - 4 } & RM1501-RM1999 & 27 & 31.4 \\
\cline { 2 - 4 } & $>$ RM2000 & 14 & 16.3 \\
\hline
\end{tabular}

\subsection{Profile of Rice Cultivation}

Most respondents carried out rice cultivation as their full-time employment $(74,86.0 \%)$. The majority of these worked on their own $(81.4 \%)$ in cultivating rice without the assistance of family members. Only 12 respondents $(14.0 \%)$ were doing it part-time. Full-time jobs for respondents who chose rice cultivation as a part-time job included traders, schoolteachers, and house builders (Table 2). The majority of farmers who cultivated rice in Pasir Panjang were tenants $(67,77.9 \%)$, but only a few owned their land $(19,22.1 \%)$. No farmers cultivated on leased land. Most farmers cultivated small farms, ranging from 1 to 2 acres only (36.0\%), with medium-sized (3-4 acres) accounting for $39.5 \%$ while nine farmers $(10.5 \%)$ worked on an area of over 7 acres (Table 2 ). Typically, the estimated value of operating costs in rice cultivation is in the range RM6000-8000 for a plot of area 3 acres. These operating costs include plowing, fertilizer and chemical pesticide inputs, and processing and other operating costs. Because the majority of the respondents cultivated more than 3 acres of rice, that is often taken as the basis for operating costs in rice cultivation. Most of the respondents (40.7\%) obtained a yield of 4-6 tons in one cultivating season, with $34.9 \%$ obtaining 1-3 tons. None of the respondents obtained a yield of more than 10 tons or above for one cultivating season (Table 2).

Table-2. Profile of rice cultivation.

\begin{tabular}{|c|c|c|c|}
\hline Profile & Category & Frequency & Percentage \\
\hline \multirow[t]{2}{*}{ Job status } & Full-time & 74 & 86.0 \\
\hline & Part-time & 12 & 14.0 \\
\hline \multirow[t]{3}{*}{ Land status } & Owned & 19 & 22.1 \\
\hline & Tenant & 67 & 77.9 \\
\hline & Leased & - & - \\
\hline \multirow[t]{4}{*}{ Farm size } & $1-2$ acres & 31 & 36.0 \\
\hline & 3-4 acres & 34 & 39.5 \\
\hline & $5-6$ acres & 12 & 14.0 \\
\hline & 7 acres and above & 9 & 10.5 \\
\hline \multirow[t]{5}{*}{ Length of time in rice cultivation } & $<1$ year & - & - \\
\hline & $1-3$ years & 5 & 5.8 \\
\hline & 4-6 years & 12 & 14.0 \\
\hline & 7-9 years & 27 & 31.4 \\
\hline & 10 years and above & 42 & 48.8 \\
\hline \multirow[t]{6}{*}{ Operating costs of rice cultivation } & $<\mathrm{RM} 2000$ & - & - \\
\hline & RM2000-4000 & 32 & 37.2 \\
\hline & RM4001-6000 & 33 & 38.4 \\
\hline & RM6001-8000 & 12 & 14.0 \\
\hline & RM8001-10 000 & 9 & 10.5 \\
\hline & RM10,000 and above & - & - \\
\hline \multirow[t]{5}{*}{ Rice yield in one season } & $<1$ ton & - & - \\
\hline & $1-3$ tons & 30 & 34.9 \\
\hline & 4-6 tons & 35 & 40.7 \\
\hline & $7-9$ tons & 21 & 24.4 \\
\hline & 10 tons and above & - & - \\
\hline
\end{tabular}




\subsection{Farmers' Level of Knowledge on Nematode attacks and Symptoms}

Studies related to farmers' level of knowledge regarding nematode attacks are very important because, without a high level of knowledge, farmers will not be able to overcome such attacks. These attacks cause physical damage to the roots, stems, and leaves, subsequently jeopardizing yield production and affecting the country's food security. Based on the percentages recorded, the majority of farmers had a level of knowledge about nematode attacks with the highest percentage value recorded in the Agree category, with 46 (53.5\%), while Strongly agree was recorded for 10 $(11.6 \%)$. The mean value was $0.747(\mathrm{~s} . \mathrm{d} .=0.865)$. Most respondents knew that there are four types of nematode that often attack rice crops: leaf nematode, root knot nematode, lesion nematode, and rice root nematode.

The majority of farmers $(52,60.5 \%)$ knew that leaf nematodes had attacked their crops (Table 3 ); they knew this based on the symptoms of the attack such as the presence of white tips on the leaf structure. The results of this study are in line with those of Fahiem and Larry (2005) and Kepenekci (2013), which recorded that the symptoms of leaf nematode attack are the presence of white tips on the leaves that will become dry and curled up.

In addition, more than half of the farmers (59, 86.6\%) agreed and strongly agreed (10.5\%) with having knowledge about the symptoms and attacks of root knot nematode on their crops. The mean value recorded was 0.377 (s.d. = 0.614) (Table 3). The symptoms of root knot nematode attack are similar to those found in studies by Mantelin et al. (2017), Karssen and Moens (2006), Fahiem and Larry (2005), Michel et al. (2005), Netscher and Erlan (1993), and Mulyadi (1997), where hook-shaped galls were noted at the root tip. This attack can cause chlorosis in rice seed, where it becomes empty and withers, in addition to reducing rice seedling numbers and decreasing crop yields.

Based on descriptive analysis, most farmers had a moderate level of knowledge about lesion nematode attacks, the mean value being 3.55 (s.d. = 1.124). Based on the mean value stated, the majority of respondents had experienced a lesion nematode attack on their crops and knew about the resulting symptoms. A total of 11 respondents (12.8\%) had limited knowledge while four (4.7\%) had no knowledge (Table 3). This nematode causes lesions on the stem of the plant (Brooks, 2013; Fahiem \& Larry, 2005; Mitiku, 2018; Perry \& Moens, 2013), these becoming brownish grey with yellowing of the leaves in 22-day-old plants (Michel et al., 2005).

The majority of farmers had knowledge of the symptoms resulting from attack by rice root nematodes. This was evidenced by the 44 respondents $(51.2 \%)$ who agreed and $20(23.3 \%)$ who strongly agreed, with a mean value of 0.597 $($ s.d. $=0.772)($ Table 3$)$. Farmers knew that the symptoms of a rice root nematode attack involve reduction in seedling numbers as well as delay in flowering by up to 14 days, as proven by the studies of Fahiem and Larry (2005), Nurjayadi et al. (2015), Michael et al. (2018), and Goswami et al. (2015). In addition, farmers also knew that the roots will turn brownish yellow and eventually the plants will rot, as evidenced by Michel et al. (2005).

Table-3. Level of farmers' knowledge on nematode symptoms and attacks.

\begin{tabular}{|c|c|c|c|c|c|c|c|c|}
\hline & \multicolumn{5}{|c|}{ Scale } & \multirow[b]{2}{*}{ Mean } & \multirow[b]{2}{*}{ Variance } & \multirow[b]{2}{*}{$\begin{array}{c}\text { Standard } \\
\text { deviation } \\
\text { (s.d.) } \\
\end{array}$} \\
\hline & 1 & 2 & 3 & 4 & 5 & & & \\
\hline \multirow{2}{*}{$\begin{array}{l}\text { Level of farmers' } \\
\text { knowledge of } \\
\text { nematode attacks }\end{array}$} & $2.30 \%$ & $7 \%$ & $25.60 \%$ & $53.50 \%$ & $11.60 \%$ & & & \\
\hline & $(2)$ & (6) & $(22)$ & $(46)$ & $(10)$ & 3.65 & 0.747 & 0.865 \\
\hline \multirow[t]{2}{*}{ Leaf nematode } & $2.30 \%$ & $5.80 \%$ & $20.90 \%$ & $60.50 \%$ & $10.50 \%$ & \multirow[t]{2}{*}{3.71} & \multirow[t]{2}{*}{0.679} & \multirow[t]{2}{*}{0.824} \\
\hline & $(2)$ & $(5)$ & $(18)$ & $(52)$ & $(9)$ & & & \\
\hline \multirow[t]{2}{*}{ Root knot nematode } & \multirow[t]{2}{*}{-} & $2.30 \%$ & $17.40 \%$ & $68.60 \%$ & $11.60 \%$ & \multirow[t]{2}{*}{3.9} & \multirow[t]{2}{*}{0.377} & \multirow[t]{2}{*}{0.614} \\
\hline & & $(2)$ & $(15)$ & $(59)$ & $(10)$ & & & \\
\hline \multirow[t]{2}{*}{ Lesion nematode } & $4.70 \%$ & $12.80 \%$ & $29.10 \%$ & $20.20 \%$ & $23.30 \%$ & \multirow[t]{2}{*}{3.55} & \multirow[t]{2}{*}{1.263} & \multirow[t]{2}{*}{1.124} \\
\hline & $(4)$ & $(11)$ & $(25)$ & $(26)$ & $(20)$ & & & \\
\hline \multirow[t]{2}{*}{ Rice root nematode } & \multirow[t]{2}{*}{-} & $3.50 \%$ & $22.10 \%$ & $51.20 \%$ & $23.30 \%$ & \multirow[t]{2}{*}{3.94} & \multirow[t]{2}{*}{0.597} & \multirow[t]{2}{*}{0.772} \\
\hline & & (3) & (19) & $(44)$ & $(20)$ & & & \\
\hline
\end{tabular}

Source: Fieldwork, 2020.

Note: $1=$ Strongly disagree; $2=$ Disagree; $3=$ Somewhat disagree; $4=$ Agree; $5=$ Strongly agree

\subsection{Impact of Nematode Attacks on Farming Economics}

The results of the study found that all farmers either agreed or strongly agreed that nematode attacks have a negative impact on the farming community, affecting farmers' source of income, reduction in their quality of life, increased cost of crop management, pesticide, and fertilizer purchases, as well as deterioration in production and harvest quality (Table 4). The results of this study are supported by Bird and Bird (2001), Nicol (2002), and Sasser and Freckman (1987), who also found that nematode attacks caused reduction in the yield of rice production, further affecting the national rate of production and consumption of rice. Yield productivity also decreased, affecting farming economics. Studies by Maisarah et al. (2018), Nurjayadi et al. (2015), Smiley (2015), Prasad, Panwar, and Rou (2008), and Mulyadi and Triman (1995) found that nematode attacks caused losses in crop yield of up to $20 \%$ of the overall harvest. Analysis of the study results found that $82.6 \%$ (71 respondents) strongly agreed and $17.4 \%$ (15) agreed that nematode attacks have affected farmers' source of income. This is due to the issues farmers had to deal with in relation to the increased cost of crop management, in addition to reduced production yield and quality. This situation had affected farmers' quality of life, which was acknowledged by all farmers, among whom 50.0\% agreed and 50\% strongly agreed that nematode attacks on crops had affected their quality of life. The mean value was 4.50 (s.d. $=$ 
0.503). Generally, harvest yields can influence farmers' total income. When yield decreases, farmers' income is affected and will have an influence on their living standards. This is because most farmers who cultivate only rice rely on the harvest as a major source of income for survival. This finding is supported by Rosmiza et al. (2015), who found that low harvest yields also affect farmers' income. Indirectly, the quality life of farmers declines because they do not have enough money to support themselves or their families. This is also evidenced by Xing et al. (2017) and Rosmiza et al. (2019), who stated that frequent disease attacks on rice crops resulted in an increase in the use of chemical pesticides. In fact, their continuous use affected the health of the local population (Lah, 2011). The results of this study are also supported by Heong et al. (2013) and Briggs (2000), who found that the appropriate use of pesticides and fertilizers is very important in overcoming the problems of rice disease. However, their continuous use can result in nematode resistance, with farmers then requiring other, additional pesticides and fertilizers. This puts pressure on farmers by incurring additional costs for crop management and is in line with the results of a study which found that all respondents agreed that rice diseases resulted in increased costs of purchasing pesticides and fertilizers. The highest score obtained in the Strongly agree category was 69.8\% (60 respondents), while the Agree category comprised $30.2 \%(26)$. The mean value was $4.70($ s.d. $=0.462)($ Table 3$)$. The results of our analysis found that a total of 61 respondents $(70.9 \%)$ strongly agreed while $25(29.1 \%)$ agreed that nematode attack resulted in severe deterioration in production yield and quality of the harvest. The mean value obtained was $4.71(\mathrm{~s} . \mathrm{d}$. $=0.457)($ Table 3). The results of this study are in line with those of Sari (2017) and Teuku (2018), who found that nematode attacks by such as $A$. besseyi can reduce the quantity and quality of harvest. This is because nematodes disrupt the growth of rice plants, causing them to change color and wither, resulting in reduction in rice seedling numbers which in turn affects yield (Fahiem \& Larry, 2005; Michel et al., 2005).

Table-4. Effects of nematode attack on production yield and farming economics.

\begin{tabular}{|c|c|c|c|c|c|c|c|c|}
\hline & \multicolumn{5}{|c|}{ Scale } & \multirow[b]{2}{*}{ Mean } & \multirow[b]{2}{*}{ Variance } & \multirow[b]{2}{*}{$\begin{array}{c}\text { Standard } \\
\text { deviation } \\
\text { (s.d.) }\end{array}$} \\
\hline & 1 & 2 & 3 & 4 & 5 & & & \\
\hline Farming economics & - & - & - & $\begin{array}{c}60.5 \% \\
(52)\end{array}$ & $\begin{array}{c}39.5 \% \\
(34)\end{array}$ & 4.40 & 0.242 & 0.492 \\
\hline Farmers' income & - & - & - & $\begin{array}{c}17.4 \% \\
(15)\end{array}$ & $\begin{array}{c}82.6 \% \\
(71) \\
\end{array}$ & 4.83 & 0.146 & 0.382 \\
\hline $\begin{array}{l}\text { Decreased quality of } \\
\text { farmers' life }\end{array}$ & - & - & - & $\begin{array}{l}50 \% \\
(43)\end{array}$ & $\begin{array}{l}50 \% \\
(43)\end{array}$ & 4.50 & 0.253 & 0.503 \\
\hline Increased crop management & - & - & - & $\begin{array}{l}36 \% \\
(31)\end{array}$ & $\begin{array}{l}64 \% \\
(51)\end{array}$ & 4.64 & 0.233 & 0.483 \\
\hline $\begin{array}{l}\text { Increased cost of purchasing } \\
\text { pesticides and fertilizers }\end{array}$ & - & - & - & $\begin{array}{c}30.2 \% \\
(26)\end{array}$ & $\begin{array}{c}69.8 \% \\
(60)\end{array}$ & 4.70 & 0.213 & 0.462 \\
\hline Loss of yield & - & - & - & $\begin{array}{c}29.1 \% \\
(25) \\
\end{array}$ & $\begin{array}{c}70.9 \% \\
(61) \\
\end{array}$ & 4.71 & 0.209 & 0.457 \\
\hline Reduced quality of yield & - & - & - & $\begin{array}{c}29.1 \% \\
(25)\end{array}$ & $\begin{array}{c}70.9 \% \\
(61)\end{array}$ & 4.71 & 0.209 & 0.457 \\
\hline
\end{tabular}

Source: Fieldwork, 2020.

Note: $1=$ Strongly disagree; $2=$ Disagree; $3=$ Somewhat disagree; $4=$ Agree; $5=$ Strongly agree

\section{CONCLUSION}

Overall, the farmers interviewed were aware of the symptoms and attacks by nematodes on the rice crops that they cultivated. In general, farmers' in-depth knowledge and their awareness about the types of diseases that attack their crops will make it easier for them to overcome such attacks. However, nematode attacks are seen as having a negative impact on farming economics and farmers' quality of life, in addition to posing a major threat to the country's rice supply security and causing deterioration in the quality and quantity of crops. This is due to the nematode's actions in the plant in the roots and stems, causing disruption to growth, leaves withering and falling off, and weedy plants. This situation puts pressure on farmers in terms of the increasing costs of crop management. If the problem persists, productivity and harvest quality will decline. Therefore, handling strategies involving control and prevention measures need to be strengthened so that nematode attacks can be overcome effectively. Chemical and biological control methods and seed treatment are seen as being able to overcome the problem of nematode attacks infesting crops. In fact, the System of Rice Intensification (SRI) method is able to increase production yield while reducing crop management costs. However, chemical control is not an environmental friendly method and will affect farm ecosystems. The combination of various techniques such as seed treatment, use of disease-resistant or -tolerant varieties, crop rotation, and use of organic materials can reduce nematode populations. Exposure through development services, such as guidance and advisory services from government agencies, can help farmers develop more efficient management methods in controlling rice diseases. As a result, farmers will be able to increase harvest productivity and thus the level of national rice security is better guaranteed. 
Funding: This research was supported by a Research University Grant, Universiti Kebangsaan Malaysia (Grant number: GGPM 2013-041).

Competing Interests: The authors declare that they have no competing interests.

Contributors/Acknowledgement: All authors contributed equally to the conception and design of the study.

Views and opinions expressed in this study are those of the authors views; the Asian Journal of Agriculture and Rural Development shall not be responsible or answerable for any loss, damage, or liability, etc. caused in relation to/arising out of the use of the content.

\section{REFERENCES}

Abdul Karim, S. (1991). Effects and control of root-knot nematodes, Meloidogyne incognita on guava trees, Psidium guajava L. (Effects and control of root-knot nematodes, Meloidogyne incognita, on guava plants, Psidium guajna L.). MARDI Research Journal, 19(1), 71-75.

Atkins, S. D., Hidalgo-Diaz, L., Kalisz, H., Mauchline, T. H., Hirsch, P. R., \& Kerry, B. R. (2003). Development of a new management strategy for the control of root-knot nematodes (Meloidogyne spp) in organic vegetable production. Pest Management Science: Formerly Pesticide Science, 59(2), 183-189.Available at: https://doi.org/10.1002/ps.603.

Auwal, H. M., Pham, T. H., Shi, H., \& Zheng, J. (2013). Nematodes threats to global food security. Acta Agriculturae Scandinavica, Section B-Soil E Plant Science, 63(5), 420-425.

Bird, D. M., Opperman, C. H., \& Davies, K. G. (2003). Interactions between bacteria and plant-parasitic nematodes: Now and then. International Journal for Parasitology, 33(11), 1269-1276.Available at: https://doi.org/10.1016/s0020-7519(03)00160-7.

Bird, D. M., \& Bird, A. F. (2001). Plant-parasitic nematodes. In Kennedy, M.W., \& Harnett, W.W. (Eds.), Parasitic Nematodes: Molecular Biology, Biochemistry and Immunology (pp. 139-166). Wallingford: CAB International Publishing.

Briggs, S. (2000). Functional genomics and the development of new plants. The Agriculture Biotechnology International Conference. Toronto, Canada.

Brooks, F. E. (2013). Burrowing nematode disease. The Plant Health Instructor: American Phytopathological Society. Retrieved from: https://www.apsnet.org.

Cheng, X., Xiang, Y., Xie, H., Xu, C.-L., Xie, T.-F., Zhang, C., \& Li, Y. (2013). Molecular characterization and functions of fatty acid and retinoid binding protein gene (Ab-far-1) in Aphelenchoides besseyi. PLoS One, 8(6), e66011.Available at: https://doi.org/10.1371/journal.pone.0066011.

Crow, W. T., \& Dunn, R. A. (2009). Managing nematodes for the non-commercial vegetable garden. Retrieved from http://ifsrvv-edis.ifas.ufl.edu/ngOO5.

Crow, W. (2013). Amaryllis lesion nematode, Pratylenchus hippeastri inserra et al., 2006 (Nematoda: Tylenchida pratylenchidae. EENY-546. IFAS Extension: University of Florida. Retrived from: https://edis.ifas.ufl.edu.

Davies, K. G. (2009). Understanding the interaction between an obligate hyperparasitic Bacterium, Pasteuria penetrans and its Obligate Plant-Parasitic Nematode Host, Meloidogyne spp. Advances in Parasitology, 68, $211-245$.

De Jesus, D. S., Oliveira, C. M. G., Roberts, D., Blok, V., Neilson, R., Prior, T., \& De Lima Oliveira, R. D. A. (2016). Morphological and molecular characterisation of Aphelenchoides besseyi and A. fujianensis (Nematoda: Aphelenchoididae) from rice and forage grass seeds in Brazil. Nematology, 18(3), 337-356.Available at: https://doi.org/10.1163/15685411-00002962.

De Waele, D., \& Elsen, A. (2007). Challenges in tropical plant nematology. Annual Review of Phytopathology, 45, 457-485.Available at: https://doi.org/10.1146/annurev.phyto.45.062806.094438.

Decraemer, W., \& Hunt, D. J. (2006). Structure and classification. In. Perry, R.N., \& Moens, M. (Eds.), Plant Nematology. Wallingford: CABI.

Department of Agriculture Sarawak. (2020). Nematode: Hidden enemy. Retrieved from doa.sarawak.gov.my.

Duncan, L. W., \& Moens, M. (2013). Migratory endoparasitic nematodes. In. Perry, R.N., \& Moens, M. (Eds.), Plant nematology (pp. 144-178). Wallingford, UK: CABI Publishing.

Fahiem, E. E. B., \& Larry, W. D. (2005). Plant parasitic nematodes in subtropical and tropical agriculture (2nd ed.). United Kingdom: CABI Publishing.

Farías, P. (2020). Promoting the absence of pesticides through product labels: The role of showing a specific description of the harmful effects, environmental attitude, and familiarity with pesticides. Sustainability, $12(21), 8912$.

Fleming, T., McGowan, N., Maule, A., \& Fleming, C. (2016). Prevalence and diversity of plant parasitic nematodes in Northern Ireland grassland and cereals, and the influence of soils and rainfall. Plant Pathology, 65(9), 1539-1550.Available at: https://doi.org/10.1111/ppa.12525.

Fofie, A., \& Raymundo, S. (1979). Parasitic nematodes in continuously cropped uplands. International Rice Research Newsletter, 4(5), 17-19.

Fuad, M. M., Junaidi, A., Habibah, A., Hamzah, J., Toriman, M., Lyndon, N., \& Azima, A. (2012). The impact of pesticides on paddy farmers and ecosystem. Advances in Natural and Applied Sciences, 6(1), 65-70.

Gonzalez-Chang, M., Tiwari, S., Sharma, S., \& Wratten, S. D. (2019). Habitat management for pest management: Limitations and prospects. Annals of the Entomological Society of America, 112(4), 1-16.

Goswami, B. K., Archana, S., Neetu, S., \& Satyendra, S. (2015). Infestation of an endoparasitic migratory rice root nematode, Hirschmanniella oryzae: A serious threat to the paddy growers of western U.P. A first report. Plant Archives, 15(2), 11951196.

Handoo, Z. A. (1998). Plant-parasitic nematodes. In USDA. Retrieved from http://www.ars.usda.gov.

Heong, K. L., Wong, L., \& Reyes, J. H. (2013). Addressing planthopper threats to asian rice farming and food security: Fixing insecticide misuse. Manila: Asian Development Bank.

Ilakiya, K., \& Kalaivani, N. (2020). A meta-analysis of quantitative trait loci associated with multiple disease resistance in rice (Oryza sativa L.). Plants, 9(11), 1491-1519.

Karssen, G., \& Moens, M. (2006). Root-knot nematodes. In. Perry, R.N. \& Moens, M. (Eds.), Plant Nematology (pp. 59-90). Wallingford: CAB International.

Kepenekci, I. (2013). Rice white tip nematode (Aphelenchoides besseyi) in rice growing areas of Turkey. Nematropica, 43(2), 181185. 
Koenning, S. R., Overstreet, C., Noling, J. W., Donald, P. A., Becker, J. O., \& Fortnum, B. A. (1999). Survey of crop losses in response to phytoparasitic nematodes in the United States for 1994. Journal of Nematology, 31(4S), 587-618.

Lah, K. (2011). Effects of pesticides on human health. Retrieved from: http://www.toxipedia.org.

Maisarah, M. S., Badrulhadza, A., Mohd, F. M., Allicia, J., Norsuha, S. M., Kogeethavani, R., \& Azmi, M. (2018). Pocket book: Pests, diseases and weeds in Malaysia (4th ed.). Malaysia: Malaysian Agricultural Research and Development Institution (MARDI): Ministry of Agriculture and Agro-based Industry.

Maisarah., M. S., \& Azmi, A. R. (2015). Pest management. In. Bukit paddy books Sariam Othman, Maisarah Mohamad Saad, Azmi Man, \& Zaki Musa (Eds.) (pp. 65-80). Serdang: MARDI.

Mantelin, S., Bellafiore, S., \& Kyndt, T. (2017). Meloidogyne graminicola: A major threat to rice agriculture. Molecular Plant Pathology, 18(1), 3-15.

Mardiana-Jansar, K., Bajrai, F., Ishak, M. S., \& Ismail, B. (2019). Effect of onduty ${ }^{\mathrm{TM}}$ herbicide on weed populations and rice yields in selected rice fields, Melaka, Malaysia. Sains Malaysiana, 48(11), 2355-2365.Available at: http://dx.doi.org/10.17576/jsm-2019-4811-07.

Michael, J., Claude, B., David, C., Thierry, C., \& Elisavet, C. (2018). Pest categorisation of Hirschmanniella spp. EFSA Journal, 16(6), 5297-5327.

Michel, L., Richard, A. S., \& John, B. (2005). Plant parasitic nematodes in subtropical and tropical agriculture (2nd ed.). Germany: University of Bon.

Mirsam, H. (2018). Inventory of plant parasitic nematodes associated with carrot plants from West Java and South Sulawesi. National Seminar Proceedings, 4(1), 273-281.

Mitiku, M. (2018). Plant-parasitic nematodes and their management: A review. Agricultural Research \& Technology: Open Access Journal, $16(2), 30-38$

Moens, M., Perry, R. N., \& Starr, J. L. (2009). Meloidogyne species - A diverse novel group and important plant parasites. In. Perry, R.N., Moens, M., \& Starr, J.L. (Eds.), Root-knot nematodes (pp. 1-17). Wallingford, UK: CAB International.

Mulyadi. (1997). Influence of root puru nematode (Meloidogyne graminicola) population on rice growth and yield. Indonesian Journal of Plant Protection, 3(1), 17-22.

Mulyadi, M., \& Triman, B. (1995). Study of host plants Nematoda Puru Root Rice (Meloidogyne graminicola). Indonesian Journal of Plant Protection, 1(1), 8-1 1.

Netscher, C., \& Erlan. (1993). A root-knot nematode, Meloidogyne graminicola, parasitic on rice in Indonesia. Afro-Asian Journal of Nematology, 3(1), 90-95.

Nguyen, N. V., \& Ferrero, A. (2006). Meeting the challenges of global rice production. Paddy and Water Environment, 4(1), 1-9.

Nicol, J. M., Turner, S. J., Coyne, L., Nijs, D. L., Hockland, Z., \& Tahna, M. (2011). Current nematode threats to world agriculture. Genomics and Molecular Genetics of Plant-Nematode Interactions, 21-43.Available at: https://doi.org/10.1007/978-94-0070434-3_2.

Nicol, J. M. (2002). Important nematode pests. In. Curtis, B.C., Rajaram, S., H. Gómez, M. (Eds.), Bread wheat improvement and production (pp. 567). FAO Plant Production and Protection Series. No. 30. Food and Agriculture Organization of The United Nations: Rome.

Nurjayadi, M., Munif, A., \& Suastika, G. (2015). Identification of the root puru nematode, Meloidogyne graminicola, in rice plants in West Java. J Fitopatologi Indonesia, $11(4), 113-120$.

Nurul, H. M. M., \& Kalaivani, N. (2014). Morphological and molecular characterization of Magnaporthe oryzae (fungus) from infected rice leaf samples. Paper presented at the The 2014 UKM FST Postgraduate Colloquium: Proceedings of the Universiti Kebangsaan Malaysia, Faculty of Science and Technology 2014 Postgraduate Colloquium.

Pam, K. (2019). Pests and diseases cause worldwide damage to crops. Retrieved form https://californiaagtoday.com/pestsdiseases-cause-worldwide-damage-crops/

Perry, R. N., \& Moens, M. (2013). Plant nematology (2nd ed., pp. 536). Wallingford, USA: CABI Publishing.

Perry, R. N., Moens, M., \& Starr, J. L. (2009). Root-knot nematodes. Wallingford, UK: CAB International.

Pracaya. (2008). Plant pests and diseases. Depok: Self-help Spreader.

Prasad, J. S., Panwar, N. S., \& Rou, Y. S. (2008). Nematode problems of rice in India. Tropical Pest Management, 33(2), $127-136$.

Rosmiza, M. Z., Amriah, B., Rosniza, A. C. R., Jabil, M. J., \& Mazdi, M. (2015). Assessment of institutional factors in determining the sustainability of rice straw entrepreneurs (An assessment of institutional factors in determining the sustainability of rice straw enterprises). Geografia-Malaysian Journal of Society and Space, 11(4), 140-151.

Rosmiza, M. Z., Rosniza, A. C. R., Jabil, M. J., \& Mazdi, M. (2019). The potential of rice straw in agricultural activities in the MADA region of Kedah, Malaysia. International Journal of Asian Social Science, 9(4), 295-303.

Ruben, M. G., Maria, V. L. J., Clarenda, P. P., Evelyn, B. G., Victor, P. G., \& Santiago, R. O. (1998). Alternative management strategies against the rice root-knot nematode, Meloidogyne Graminicola in a rice-onion system (pp. 218-224). VISCA, Technical Papers: Agricultural Sciences Division.

Sari, M. F. (2017). The effect of aphelenchoides besseyi christie nematode infection on seeds on the growth of rice plants. Bogor: IPB.

Sasser, J. N., \& Freckman, D. W. (1987). A world perspective on nematology: Role of society. In. Veech, J.A., \& Dickson D.W. (Eds) (pp. 7-14). Maryland: Vistas on Nematology, Society of Nematologists, Hyattsville.

Sasser, J. N. (1977). Worldwide dissemination and importance of the Root-knot nematodes, Meloidogyne spp. Journal of Nematology, 9(1), 26-29.

Smiley, R. W. (2015). Root-lesion nematodes, biology and management in Pacific Northwest wheat cropping systems (pp. 1-14): Oregon State University: A Pacific Northwest Extension Publication.

Teuku, S. T. H. (2018). Effect of aphelenchoides besseyi christie on vegetative growth of IPB $3 S$ variety. Bogor: IPB.

Tülek, A., Ates, S. S., Akin, K., Surek, H., Kaya, R., \& Kepenekci, I. (2014). Determining yield losses in rice cultivars resulting from rice white tip nematode Aphelenchoides besseyi in field condition. Pakistan Journal of Nematology, 32(2), 149-154.

Xing, H. X., Jun, Y. Y., Hui, L. Y., Song, Z. X., Jun, T., Feng, L., \& Xian, L. Z. (2017). Sustainable management of rice insect pests by non-chemical-insecticide technologies in China. Rice Science, 24(2), 61-72.

Yamane, T. (1967). Statistics: An introductory analysis (2nd ed.). New York: Harper and Row. 